\title{
Effect of Simulated Climate Warming on the Ectomycorrhizal Fungal Community of Boreal and Temperate Host Species Growing Near Their Shared Ecotonal Range Limits
}

\author{
Joanna Mucha $^{1}$ - Kabir G. Peay ${ }^{2}$ Dylan P. Smith ${ }^{3}$ - Peter B. Reich ${ }^{4,5}$. \\ Artur Stefański ${ }^{4}$ - Sarah E. Hobbie ${ }^{6}$
}

Received: 10 January 2017 / Accepted: 13 July 2017 / Published online: 25 July 2017

(C) The Author(s) 2017. This article is an open access publication

\begin{abstract}
Ectomycorrhizal (ECM) fungi can influence the establishment and performance of host species by increasing nutrient and water absorption. Therefore, understanding the response of ECM fungi to expected changes in the global climate is crucial for predicting potential changes in the composition and productivity of forests. While anthropogenic activity has, and will continue to, cause global temperature increases, few studies have investigated how increases in temperature will affect the community composition of ectomycorrhizal fungi. The effects of global warming are expected to be particularly strong at biome boundaries and in the northern latitudes. In the present study, we analyzed the effects of experimental manipulations of temperature and canopy structure (open vs. closed) on ectomycorrhizal fungi identified from roots of host seedlings through 454 pyrosequencing. The ecotonal boundary site selected for the study
\end{abstract}

Electronic supplementary material The online version of this article (doi:10.1007/s00248-017-1044-5) contains supplementary material, which is available to authorized users.

Joanna Mucha jmucha@man.poznan.pl

1 Institute of Dendrology, Polish Academy of Sciences, Kórnik, Poland

2 Department of Biology, Stanford University, Stanford, CA 94305, USA

3 University of California, California Institute for Quantitative Biosciences, Berkeley, CA, USA

4 Department of Forest Resources, University of Minnesota, St. Paul, MN, USA

5 Western Sydney University, Hawkesbury Institute for the Environment, Penrith, NSW, Australia

6 Department of Ecology, Evolution and Behavior, University of Minnesota, St. Paul, MN, USA was between the southern boreal and temperate forests in northern Minnesota, USA, which is the southern limit range for Picea glauca and Betula papyrifera and the northern one for Pinus strobus and Quercus rubra. Manipulations that increased air and soil temperature by 1.7 and $3.4^{\circ} \mathrm{C}$ above ambient temperatures, respectively, did not change ECM richness but did alter the composition of the ECM community in a manner dependent on host and canopy structure. The prediction that colonization of boreal tree species with ECM symbionts characteristic of temperate species would occur was not substantiated. Overall, only a small proportion of the ECM community appears to be strongly sensitive to warming.

Keywords Belowground communities - Ecotonal boundary · Temperature increase $\cdot$ Ectomycorrhizal fungi

\section{Introduction}

Boreal forests are expected to experience some of the most extreme increases in air temperature as a result of climate change. An increase of $1.5^{\circ} \mathrm{C}$ has already been observed in the boreal zone [1], with additional warming of $4-6{ }^{\circ} \mathrm{C}$ expected in the next century [2]. As climatic conditions (predominantly temperature and precipitation) can influence the geographical distribution of plant species [3], future warming is likely to significantly impact the biology of resident species. Higher temperatures may prolong the growing season, extend plant water and nutrient uptake, and lead to changes in above and below ground net primary production and litter quality [4]. Increased rates of decomposition in boreal forests may enhance the loss of carbon from previously frozen soils and affect plant growth through increased mineralization of organic nutrients [5]. These environmental changes may be of special importance to boreal plant species that have 
evolved adaptations to reduced nutrient cycling rates that include the allocation of relatively more biomass to fine roots [6] and the production of absorptive fine roots with a relatively thick root cortex suitable for colonization by ectomycorrhizal fungi [7]. Roots associated with symbiotic microbes are able to optimize nutrient absorption under diverse environmental conditions [8]. Ectomycorrhizal fungi (ECM) are responsible for the majority of nutrient uptake in boreal tree species [9] and constitute a direct link between the above- and belowground components of boreal ecosystems. Thus, the loss or gain of mycorrhizal symbionts may affect host tolerance to changing climatic conditions [10], especially at the trailing, southern edges of boreal plant ranges. Although the geographical range of boreal species is expected to recede northwards while the range of temperate species is expected to expand, boreal species still occupy and function, despite decreased growth, in the transition zone between temperate and boreal species [11]. Given the interaction that occurs in the transition zone, limited knowledge exists pertaining to the response of the ectomycorrhizal community to climate change and how it might mediate changes in the community structure of boreal forests.

The response of ectomycorrhizal fungi to climate change will be affected by several factors that may alter the strength of the above/belowground linkage. Modified climatic conditions can affect mycorrhizal fungi directly and also through effects on the symbiotic partner, which may indirectly have an effect on the mycorrhizal fungal community. Mycorrhizal colonization is dependent on carbon allocation to roots by host plants, with up to 20 $30 \%$ of seedling assimilate being allocated to ECM fungi [12]. This carbon source is directly used for the growth of extensive mycelial networks [13]. Tree species growing in the nitrogen-limited environment of boreal forests have higher relative allocation of tree photosynthate to their microbial symbionts compared to trees growing in fertile habitats [14], which in turn can improve tree $\mathrm{N}$ nutrition by means of fungal-mediated nutrient uptake from soil [15]. Patterns of carbon allocation within tree change significantly with forest structure, peaking in belowground with canopy closure, where leaf area index and nutrient demand are maximal $[16,17]$. As boreal tree species show reduced photosynthesis with warming at the borealtemperate ecotone, and temperate trees increased rates [18], this may signal reduced flow of carbohydrate to ECM fungi of boreal species under warmer climate conditions, resulting in the promotion of less carbon demanding species [19]. Previous research has demonstrated that carbon productivity increases ectomycorrhizal diversity $[20,21]$. Therefore, temperate species growing near their northern range limit may support a higher diversity of ECM or investment in extramatrical hyphae due to the increased belowground carbon allocation that may occur due to increased regional temperature.

Fungi can grow under a wide range of temperatures [22]. Reduced species dissimilarity, however, may have an adverse effect on an ecosystem due to antagonistic interactions [23], as was reported for ECM isolates colonizing host plant roots under increased competition among fungi [24]. Thus, increasing the taxonomic, morphological, and functional diversity of ECM fungi may allow host plants to tolerate changes in environmental conditions in the broader geographical range, especially under warming and/or drying conditions [25]. Results of previous studies on the effects of warming on ECM symbiosis have been somewhat mixed. Warming experiments have been reported to cause changes in biomass and community composition of ECM fungi observed in several studies in the arctic tundra [26, 27] and boreal forests [28], as well as in growth chamber studies [29, 30]. Air temperature, however, has been reported to have a minimal influence on the community composition of ECM fungi at a regional scale [31] or on the richness of ECM fungi over substantial gradients including temperature [32, 33]. Most studies, however, have focused on a single species, which may obscure important effects of warming as species replacement occurs along range boundaries of temperate and boreal taxa. Including a greater number of plant species in studies may be important since host identity can have a strong influence on species richness and the community composition of ECM fungi [34-36]. Meta-analyses of many plant species have indicated that a lower phylogenetic diversity of ECM taxa exists in subarctic and tropical zones $[37,38]$, implying that an environmental filtering occurs at both high and low temperatures. Climate and host identity parameters, however, are confounded in studies over large geographic areas, leaving the primary drivers of these patterns unclear.

In order to determine how ectomycorrhizal communities respond to climate change, we assessed the composition of ectomycorrhizal fungi on seedlings in a long-term temperature manipulation experiment (B4WarmED) [18] in northern Minnesota at the ecotone between temperate and boreal forests. Root communities of planted juveniles of deciduous and conifer species representative of the boreal and temperate zones were surveyed using next-generation DNA sequencing. The sampling also included a canopy manipulation in order to determine how factors such as light availability might modify ECM fungal community response to global climate change (GCC). Previous research in this experiment demonstrated that in response to elevated temperatures (simulated climate warming), temperate species at their northern range limit increased their photosynthesis and growth while boreal species at their southern range limit decreased their photosynthesis and growth [18]. We hypothesized that, correspondingly, ECM fungal richness would increase in temperate hosts in the warmed plots and decrease in boreal hosts. In addition, 
we hypothesized that ECM fungal community composition in the warmed plots would be dominated by fungi found on temperate host plants. Lastly, we expected that richness would increase in open canopy plots due to increased belowground carbon allocation.

\section{Material and Methods}

Research Site and Sampling The study site is located in an upland forest at the Cloquet Forestry Center in Cloquet, Minnesota USA $\left(46^{\circ} 31^{\prime} \mathrm{N}, 92^{\circ} 30^{\prime} \mathrm{E}, 386\right.$ a.s.1.). The site has a mean annual temperature of $4.5^{\circ} \mathrm{C}$ and a mean annual precipitation of $807 \mathrm{~mm}$. The B4Warmed project (Boreal Forest Warming at an Ecotone in Danger) is located in a natural mixed aspen-birch-fir stand (approx. 40-60 years old) [18]. Soils are classified as the Omega-Cloquet-Cromwell association and consist of a sandy loam with a gravelly underlying material. Experimental plots in the B4Warmed site were planted with nursery-grown seedlings established from local seed of five boreal (Picea glauca, Pinus banksiana, Abies balsamifera, Betula papyrifera, and Populus tremuloides) and five temperate (Acer sacharum, A. rubrum, P. strobus, Quercus macrocarpa, and Q. rubra) tree species in the native ground vegetation. Temperature treatments included a treatment control (inactive heating cables and lamps) and warming treatments of +1.7 and $+3.4{ }^{\circ} \mathrm{C}$ above ambient temperature [39]. The differences in temperature were +1.7 and $+3.4{ }^{\circ} \mathrm{C}$ belowground at the depth of $10 \mathrm{~cm}$ and +1.82 and $+3.45^{\circ} \mathrm{C}$ aboveground for the plant canopies [39]. Plants were heated both aboveground with overhead infrared heat lamps and belowground with buried heating cables at the depth of $10 \mathrm{~cm}$. Seedlings were transplanted into the plots in the spring of 2008. The warming treatments were applied continuously for $24 \mathrm{~h} /$ day for approximately 8 months/year from about March to November starting in the spring of 2009. Temperature treatments were administered in a fully factorial design with two treatments that were designed to replicate understory ( $\sim 5-10 \%$ of full light) and open ( $\sim 40-60 \%$ of full light) conditions, similar to what might occur after timber harvest. Greater technical details regarding the B4Warmed Project are available in Rich et al. [39].

In order to characterize the ECM fungal community, roots were sampled from four species growing in the B4WarmED experimental plots. The sampling included two boreal (P. glauca and B. papyrifera) and two temperate (P. strobus and $Q$. rubra) tree species. The chosen species represent conifer and angiosperm species from each zone since they differ in anatomy and physiology and may respond differently to warming [see 40]. Roots were collected in March, 2012 during destructive harvests of trees, directly from intact root systems of 2 to 7 individuals of each species. As a result, the host identity was known. The sampling included 3 temperature treatments $\times 2$ canopy treatments $\times 4$ species $\times 2$ to 7 seedlings which provided a total $N=129$. For each individual, $15 \mathrm{ECM}$ root tips were removed from each individual under a dissecting scope from a random collection of different root fragments gently washed in water. Bulked ECM root tips were placed in tubes filled with $300 \mu \mathrm{L}$ of $2 \times \mathrm{CTAB}$ buffer [41] and frozen at $-80{ }^{\circ} \mathrm{C}$ until further processing. Four to seven seedlings for each unique treatment (species $\times$ canopy $\times$ temperature) were taken from different plots.

DNA Extraction, PCR Amplification, and Sequencing Root tips were homogenized using three 3-mm zirconia beads in a tissue homogenizer (FastPrepTM FP120, Thermo Savant, Qbiogene, Carlsbad, CA) at a speed setting of 5.5 for $45 \mathrm{~s}$. DNA was then extracted from the homogenized samples using a Qiagen Tissue Kit (Qiagen, Valencia, CA, USA) according to the manufacturer's protocol (Qiagen, Valencia, CA, USA), with the addition of a preliminary chloroform extraction as described by Peay et al. [41]. PCR reactions were performed in a total volume of $25 \mu \mathrm{l}$ consisting of $0.125 \mu \mathrm{l}$ of HotStarTaq polymerase $(5 \mu / \mu \mathrm{l}$, Qiagen, Valencia, CA, USA), $5 \mu \mathrm{l}$ of $5 \times$ PCR buffer, $0.5 \mu$ l of each of the $10 \mu \mathrm{M}$ the primers, $5 \mu \mathrm{l}$ of $10 \mathrm{mM} \mathrm{dNTP}$, and $1 \mu \mathrm{l}$ of template DNA. The internal transcribed spacer (ITS) region of the nuclear ribosomal RNA genes was amplified using the fungal specific primer pair ITS1f [42] and ITS4 [43]. The primers were modified for next-generation sequencing on the 454 platform by adding an A adapter to the $5^{\prime}$-CCATCTCATCCCTGCGTGTC TCCGACTCAG- $3^{\prime}$ and a 10 base pair barcode to the $5^{\prime}$ end of the ITS1F primer and the $454 \mathrm{~B}$ adapter $5^{\prime}$-CCTA TCCCCTGTGTGCCTTGGCAGTCTCAG- $3^{\prime}$ to the $5^{\prime}$ end of the ITS4 primer. Cycling conditions were as follows: after an initial denaturation step at $95^{\circ} \mathrm{C}$ for $1 \mathrm{~min}, \mathrm{PCR}$ was cycled 30 times at $94^{\circ}$ for $30 \mathrm{~s}$, at $52^{\circ} \mathrm{C}$ for $30 \mathrm{~s}$, at $68^{\circ} \mathrm{C}$ for $1 \mathrm{~min}$, followed by a final extension at $68^{\circ} \mathrm{C}$ for $7 \mathrm{~min}$. Negative controls were included alongside all DNA extractions, and PCR reactions provided clean products as determined by gel electrophoresis. Successful PCR products were purified using Agencourt AMPure XP (Beckman Coulter, Brea, California) following the manufacturer's instructions and quantified using the Quant-iT dsDNA HS Assay Kit (Life Technologies, Carlsbad, California). Samples were pooled in equimolar concentrations and sequenced at the Duke University ISGP Sequencing Facility on a 1/8 partition of a 454 Life Sciences FLX Titanium Shotgun plate (454 Life Sciences).

Bioinformatics Qiime v. 1.7.0. [44] was used to process the resulting 454 dataset. For quality control, all reads with more than 1.5 barcode error, no valid primer or DNA tag, or any sequences with ambiguous bases or those that were shorter than the length threshold of $<350 \mathrm{bp}$, were removed. After quality control, the dataset was reduced from 72,168 to 41,637 reads. The remaining sequences were assigned to 
operational taxonomic units (OTUs) with the USEARCH algorithm [45] using a $97 \%$ sequence identity and default parameters for minimum overlap, matches, mismatches, and gap penalties. A taxonomic designation was assigned to a representative sequence from each OTU using the BLAST option in QIIME's assign_taxonomy.py script against the UNITE v6 database [46; http://unite.ut.ee/repository.php] with dynamic clustering threshold accessed on 30 December 2014. The OTU table was filtered to include only confirmed or potential ECM taxa based on Tedersoo et al. [47] and Branco et al. [48]. After filtering for ECM fungal taxa, we rarefied the OTU table to 50 sequences per sample using the multiple_rarefaction.py script, a level that maximized sample retention while still providing adequate sequencing depth. Diversity indices (chao1, observed species, Shannon diversity, Simpson diversity, Shannon and Simpson evenness, and phylogenetic diversity) were calculated at a depth of 50 sequences using the alpha_diversity.py script in Qiime.

Statistical Analysis A general linear model (GLM) was used to test whether or not temperature, canopy manipulations, and host species affected fungal diversity metrics. The statistical model included all main effects and pairwise interactions of main factors. A three-way interaction, however, was not included with all of the studied factors in our model due to the lack of appropriate replication. A t-statistic was applied to estimate significance of fixed effects $(P=0.05)$, and pairwise differences between treatment groups were assessed with Tukey's honest significant difference (HSD) test.

Despite the variability in PCR efficiency [49, 50] and ITS copy number [51, 52], which may vary across taxa, quantitative sequence data are more accurate than presence-absence data in estimating community differences [53, 54]. Similarly, Amend et al. [55] found that relative abundance across samples was also a reliable measure. For this reason, we based our analyses of community composition on sequence abundance data. To test which factors were significant drivers of variability in ECM fungal community composition, temperature, canopy, and host, and their interaction, were used as predictor variables for multispecies generalized linear models (GLM) applied by means of the R package mvabund [56]. In contrast to dissimilarity-matrix-based methods, mvabund avoids confounding location with dispersion effects, which can inflate type 1 and type 2 errors [57]. The "negative.binomial" was used as suggested for multivariate abundance models based on count data [58]. Multiple tests were corrected for using the $p$.adjust $(\operatorname{method}=$ " $f d r ")$ function in R's base package. $P$ values were determined based on 1000 permutations. Redundancy analysis (RDA) in the VEGAN package of $\mathrm{R}$ ( $\mathrm{R}$ Core Development
TEAM, 2007) was used to visualize the potential impact of temperature treatment on the fungal community.

\section{Results}

\section{Taxonomic Coverage}

A total of 41,517 sequences were generated and assigned to 358 OTUs (Table S1). Within the OTUs, 292 (48.5\% of sequences) matched other fungi, 84 (51.4\% of sequences) ECM, $2(0.005 \%$ of sequences $)$ were unidentified fungi, and 7 $(0.075 \%$ of sequences $)$ received no blast hit. Among the OTUs, 174 (77\% of sequences) were classified as Basidiomycota and 130 (22\% of sequences) belonged to the Ascomycota (Tables S1, S2, S3). The Zygomycota and Glomeromycota were represented by 23 ( $0.45 \%$ of sequences) and $22(0.95 \%$ of sequences $)$ OTUs, respectively. The most frequently encountered ECM taxa belonged to the genera Lactarius, Laccaria, Tomentella, Russula, Hebeloma, and Tuber (Table 1), and the greatest number of ECM OTUs were found in Inocybe and Tomentella (OTUs 16 and 15, respectively). The most common ECM fungal taxa were found in less than $25 \%$ of the samples.

\section{Treatment Effects on Fungal Community Composition}

Taxa that responded to experimental treatment were generalists (in reference to host compatibility) such as Laccaria, Russula, and Tomentella [59, 60], and we did not find increase of ECM fungal species with long exploration type characterized for warmer conditions. Two ECM taxa, Lactarius (OTU_2) and Russula (OTU_44), decreased in occurrence in the higher $\left(3.4^{\circ} \mathrm{C}\right)$ temperature treatment, in contrast to Wilcoxina (OTU_10 and OTU_24) and Laccaria (OTU_37), which increased in both higher temperature treatments (Table 1). Lactarius (OTU_2 and OTU_134) and several Tomentella (OTU_4, OTU_6 and OTU_59) and Russula (OTU_44) species were frequently present in closed canopy samples. Tomentella, Clavulina, and Tuber species exhibited diverse responses to the elevated temperature treatments.

Species that were potentially mycorrhizal or associated with mycorrhiza were identified among the other fungal taxa. The most frequently encountered species was Phialocephala fortinii (Table 2), which occurred in more than half of the samples. This taxon, however, was represented by only 3 OTUs in contrast to the more diverse Mortierella which was represented by 14 OTUs. The vast majority of taxa were found in less than $25 \%$ of the samples.

Abundance data indicated that all of the experimental factors (host species, canopy, and temperature treatment) had a significant influence on ECM fungal community composition (Table 3 and Fig. 1) and other fungal taxa 


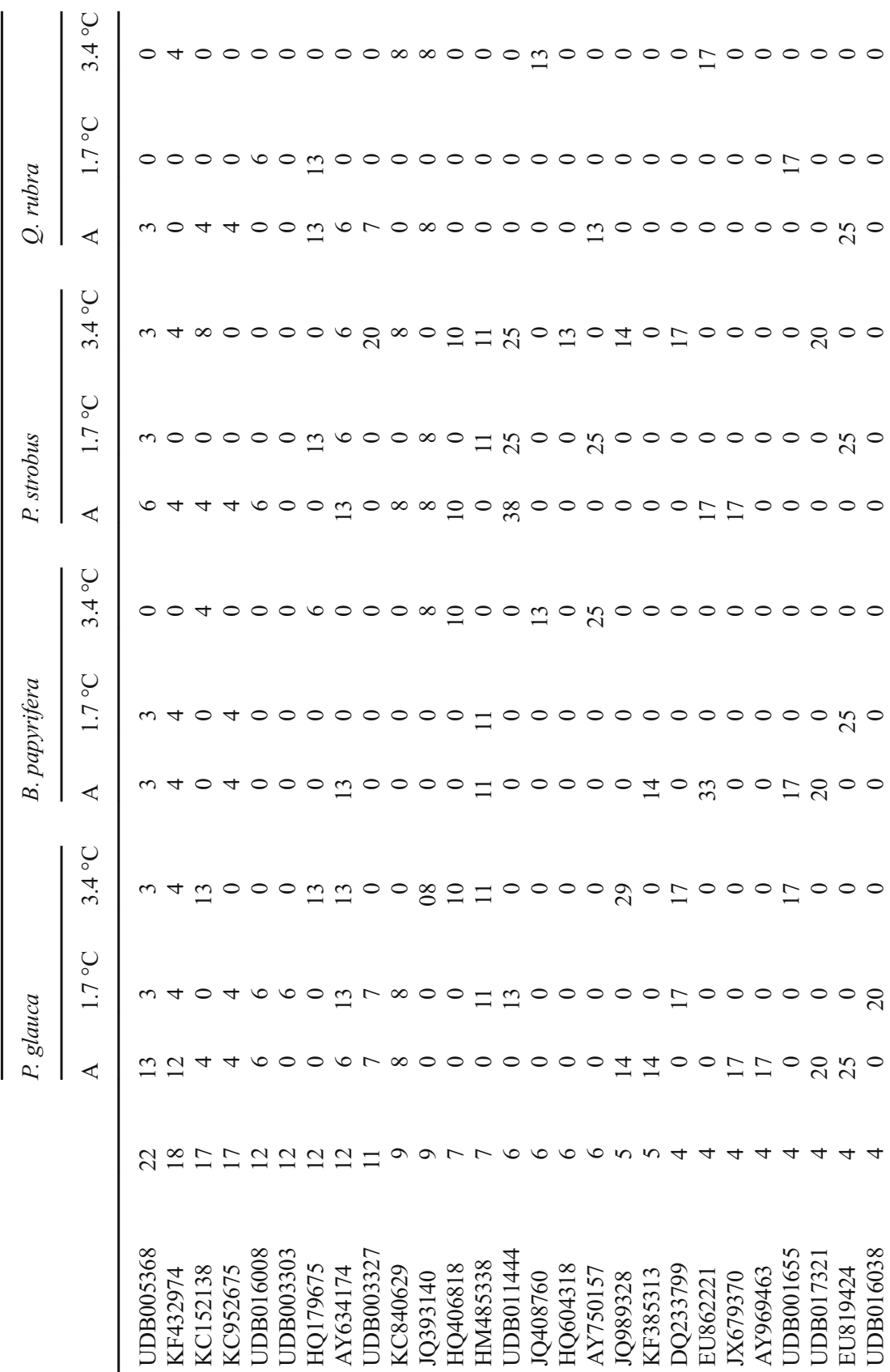

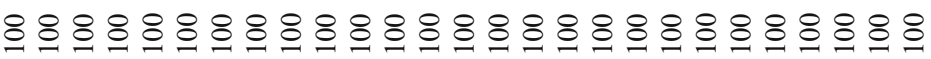

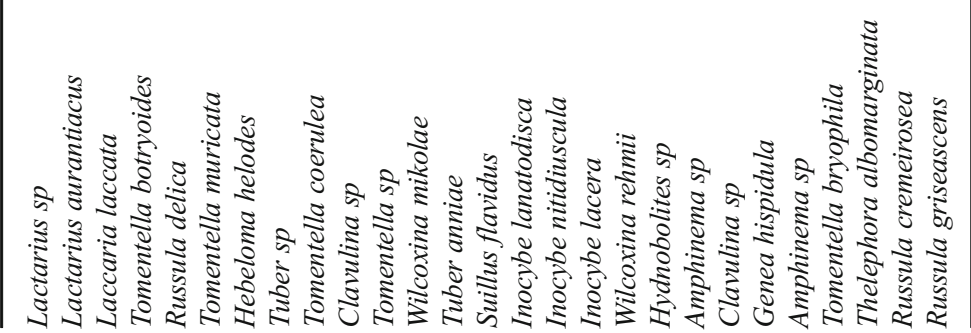

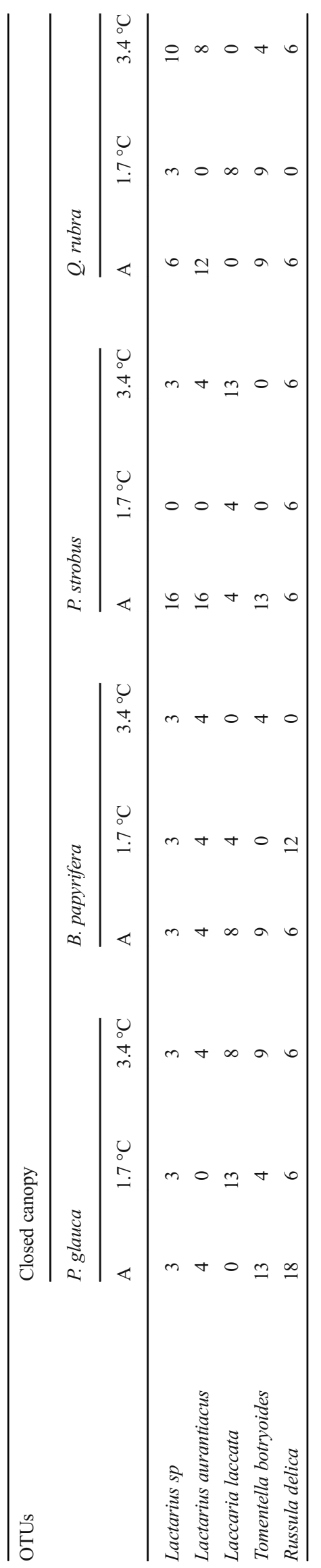




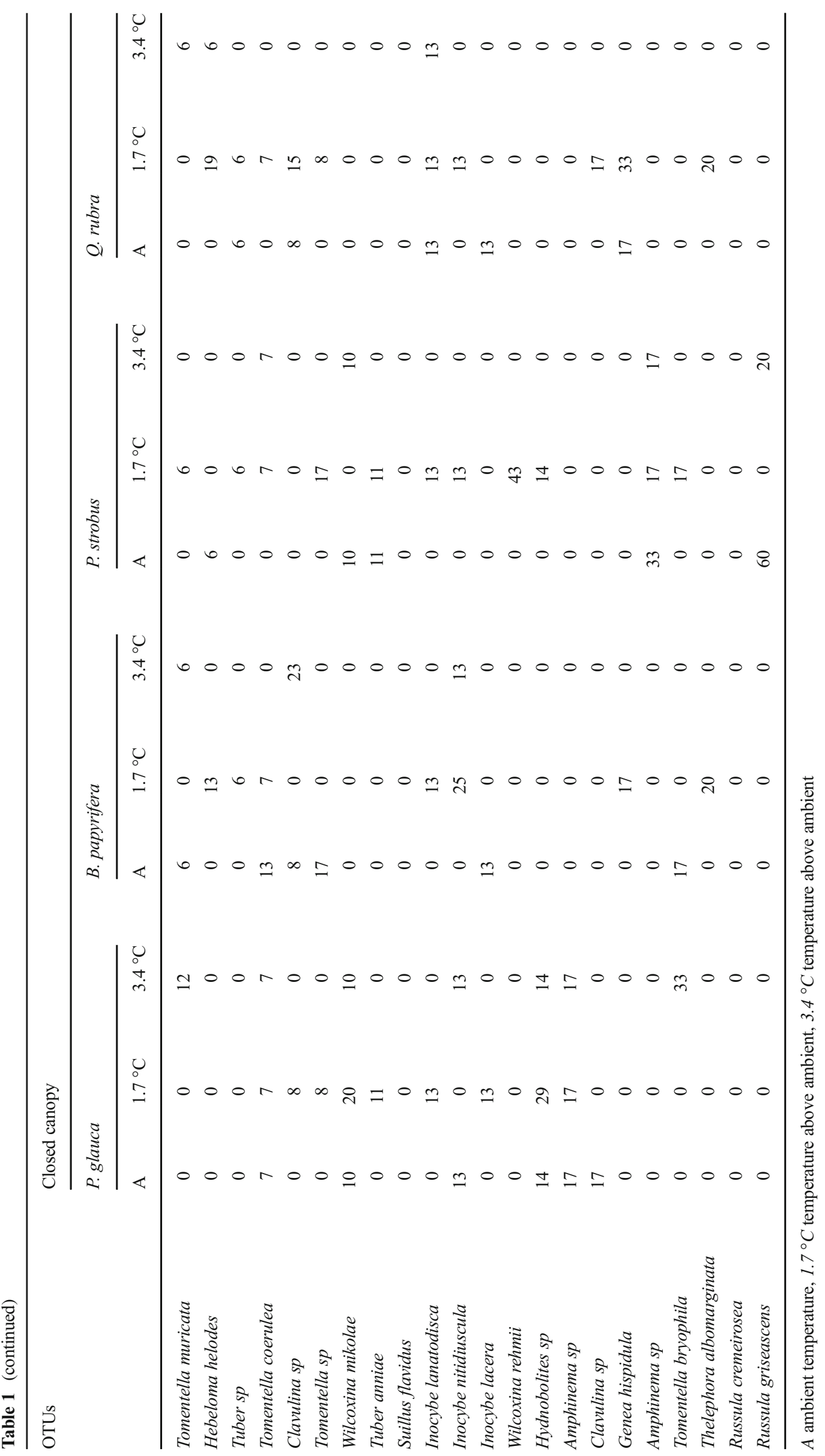




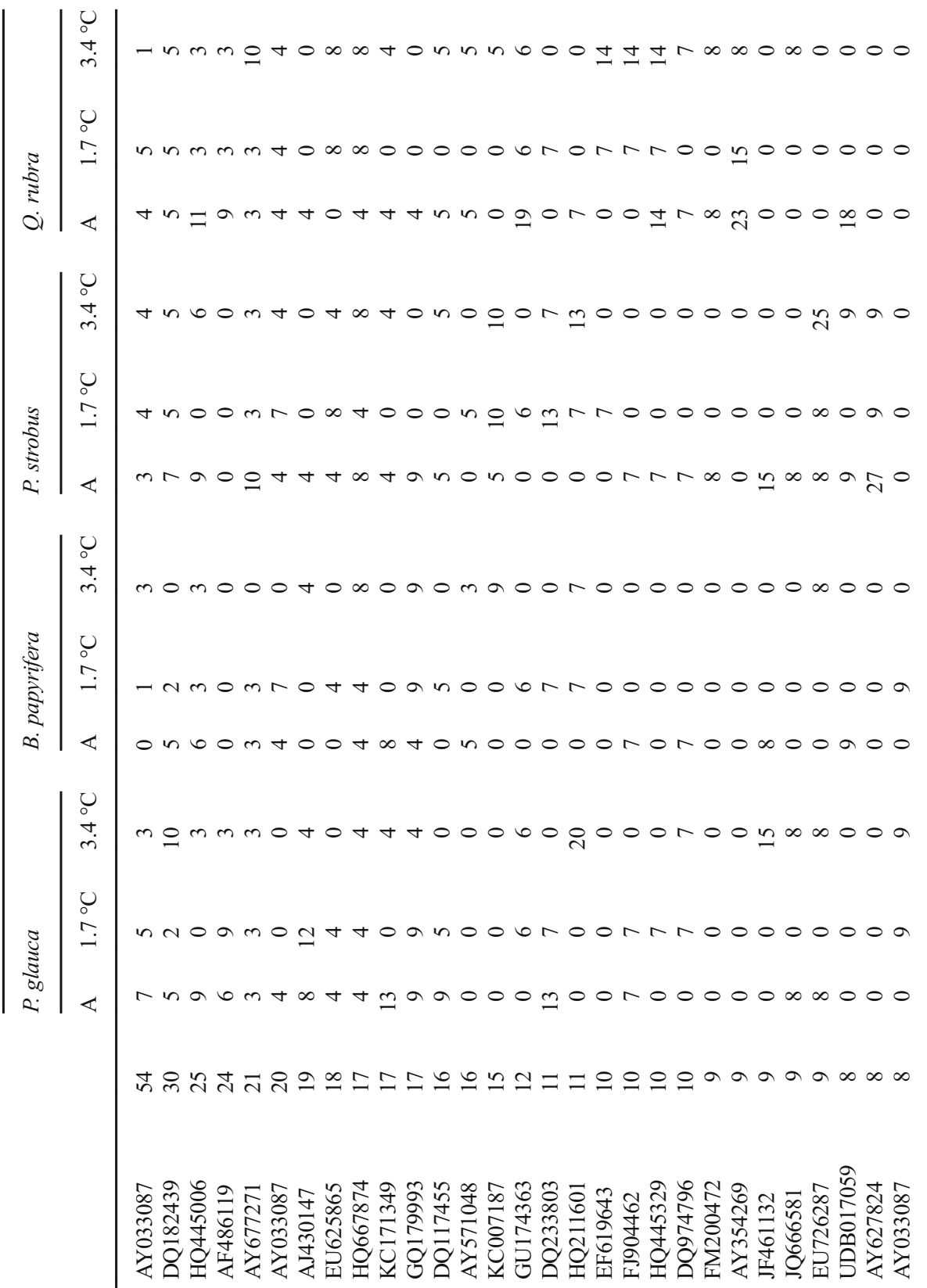

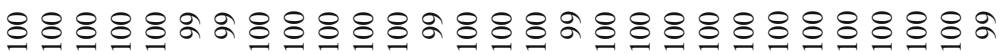

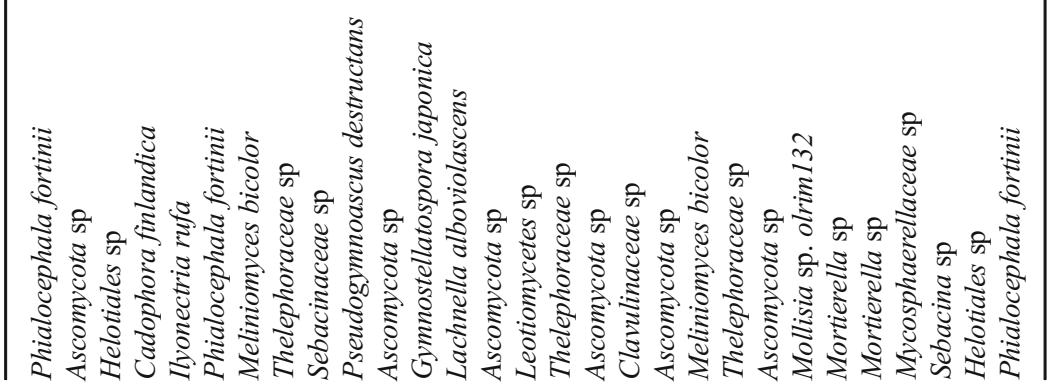

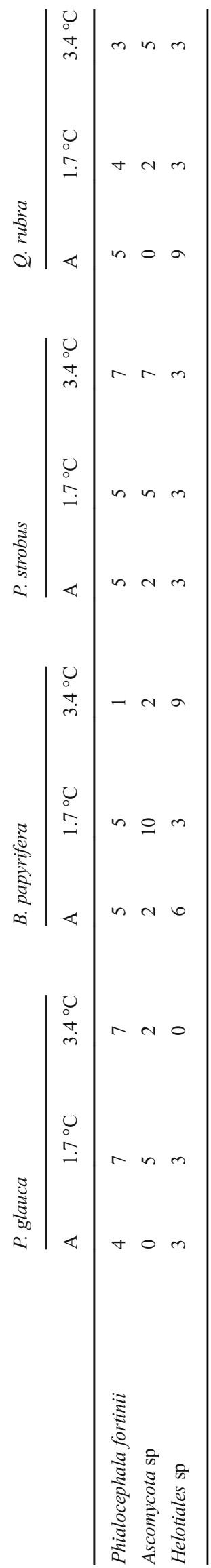




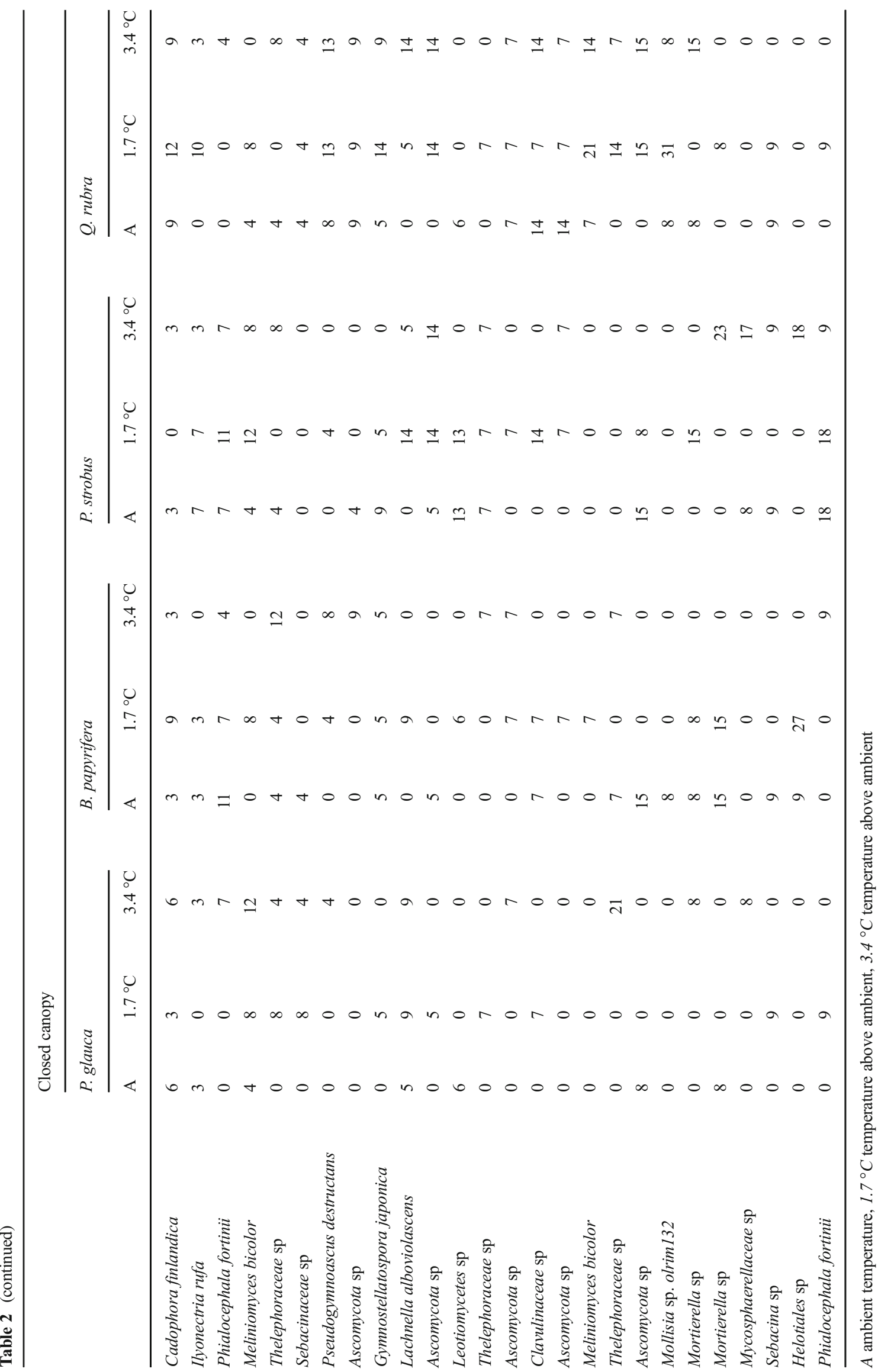


Table 3 Multivariate test (nmanyglm) of ECM abundance taxon

\begin{tabular}{llrl}
\hline Factor & Res. Df & Score & $\operatorname{Pr}(>$ score $)$ \\
\hline Canopy & 120 & 131.6 & 0.001 \\
Temperature treatment & 121 & 253.1 & 0.001 \\
species & 123 & 358.3 & 0.001 \\
Canopy $\times$ temperature treatment & 109 & 117.5 & 0.001 \\
Canopy $\times$ species & 111 & 149.8 & 0.001 \\
Temperature $\times$ species & 114 & 292.8 & 0.001 \\
Canopy $\times$ temperature treatment $\times$ species & 103 & 41.4 & 0.001 \\
\hline
\end{tabular}

community composition (Table 4). Although we expected shifts in community composition across temperature, we did not confirm domination of ECM fungi characteristic to temperate species in the warlmer plots (those belong to long-distance exploration type). Four ECM fungal OTUs responded to treatments. Univariate tests confirmed that Laccaria laccata (OTU 37) and Clavulina sp. (OTU 30) varied among plant host species and temperature treatment, respectively. L. laccata was significantly more abundant $(P=0.020)$ on $P$. abies, B. papyrifera, and $P$. strobus than on $Q$. rubra roots, while Clavulina sp. was significantly more abundant $(P=0.014)$ in the ambient versus warm temperature treatments. A significant interaction $(P=0.019)$ between host species and temperature was demonstrated for the relative abundance of Russula delica (OTU_44) (Fig. 2a). R. delica was also more abundant at the ambient and lower, elevated temperature (1. $7{ }^{\circ} \mathrm{C}$ ) on conifers and B. papyrifera roots but was barely detected on $Q$. rubra roots (relative abundance $<1 \%$ ). The occurrence of $L$. laccata revealed a contrasting response to temperature treatment and canopy. Specifically, it increased in abundance with elevated temperatures in the open canopy and the opposite trend occurred in the closed canopy $(P=0.002)$. The abundance of Tomentella coerulea (OTU_6) was affected by an interaction of canopy, temperature, and species $(P=0.020)$ (Fig. 2b, c).

\section{Treatment Effects on Fungal Community Diversity}

Although we expected that ECM richness would increase on temperate hosts and decrease on boreal hosts in response to temperature, ECM fungal richness (Chao1) was consistent for temperate and boreal species across temperature treatments (three-way ANOVA; host $\times$ temperature treatment interaction $\mathrm{F}=1.521$, d.f. $=6, P=0.181$ ) (Table 5). We did not observe dissimilarity across temperature treatments (three-way ANOVA; $\mathrm{F}=0.452$, d.f. $=2, P=0.638)$ and host species (three-way ANOVA; $\mathrm{F}=0.132$, d.f. $=3, P=0.941$ ). Additionally, in contrast to our hypothesis that increased belowground carbon allocation in open plots would promote greater ECM richness, no difference in Chao richness was observed between canopy conditions (three-way ANOVA; $\mathrm{F}=0.044$, d.f. $=1, P=0.834$ ). The use of other diversity metrics (Shannon diversity and evenness, Simpson diversity and evenness, and phylogenetic diversity) gave similar results and did not show significant effects of host species, temperature treatment, or canopy individually or by their pairwise interaction on these indices and did not confirm our hypothesis. Analysis of other species revealed that the canopy treatment influenced richness and diversity, with the highest mean values obtained under closed canopy, opposite of what we expected (Table 6). Different patterns of richness for other fungi were observed in open vs. closed canopy treatments across temperature (canopy $\times$ temperature treatment interaction). Estimated richness was the highest under closed canopy treatments at $1.7{ }^{\circ} \mathrm{C}$ and both temperatures $\left(1.7\right.$ and $\left.3.4{ }^{\circ} \mathrm{C}\right)$ in an open canopy.

\section{Discussion}

In the present study, we investigated how projected increases in global temperatures will affect root ECM fungi of boreal and temperate tree species, and how this might interact with canopy structure. Host species [34, 35, 61], soil quality [31, $62]$, and canopy structure $[17,63]$ have all been previously reported to influence ECM fungal community composition. Studies that are able to control host species identity across broad geographic ranges have also showed climatic conditions to have a strong impact on ECM fungal community

a

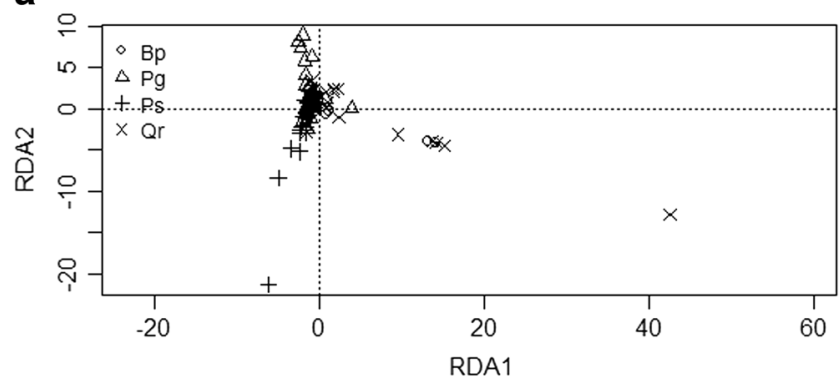

b

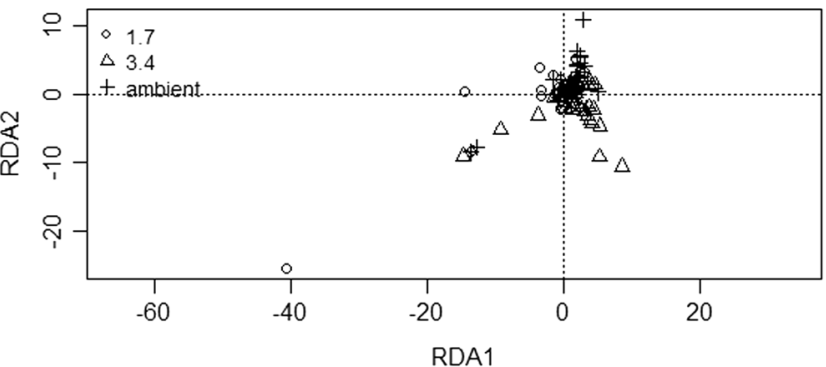

Fig. 1 Ordination diagram illustrating the effects of species - Picea glauca (Pg), Betula papyrifera (Bp), Pinus strobus (Ps), and Quercus rubra (Qr) (a) or temperature treatment (ambient, $+1.7^{\circ} \mathrm{C}$, and $3.4^{\circ} \mathrm{C}$ ) (b) based upon RDA analysis of ECM fungal communities 


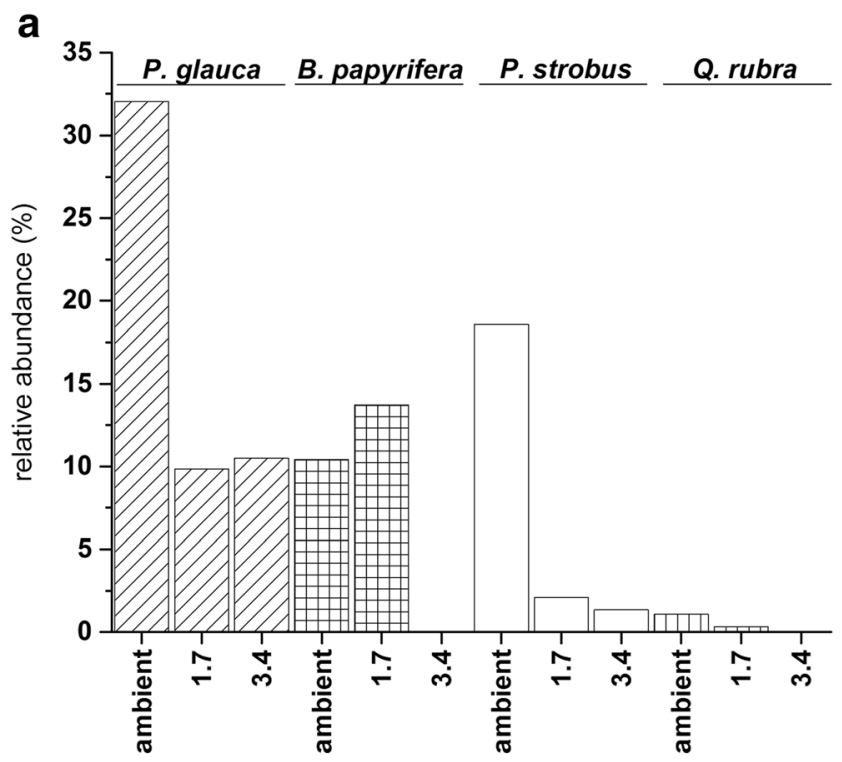

b

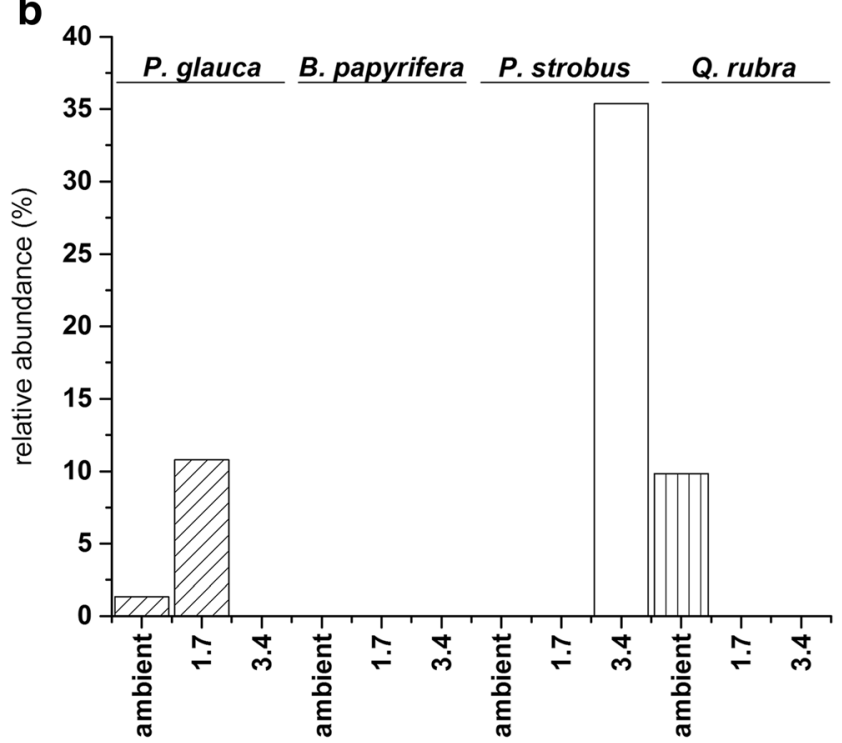

C

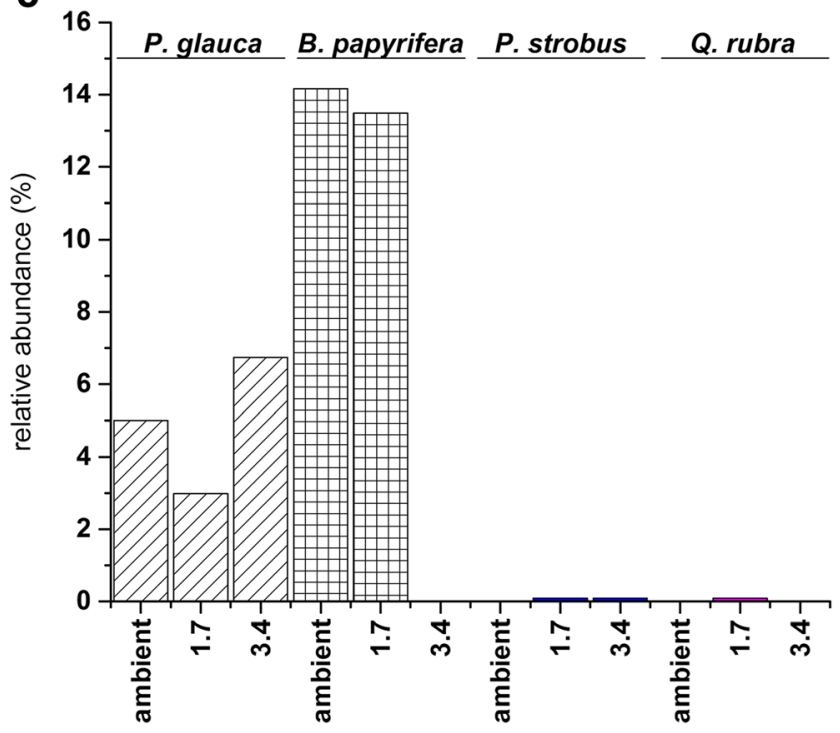

Fig. 2 Relative abundance of selected OTUs under different experimental conditions. a Russula delica (OTU_44) abundance (species $\times$ temperature treatment). b Tomentella coerulea (OTU_6) in an open canopy. c Tomentella coerulea (OTU_6) in a closed canopy

[33, 64, 65]. Similarly, in our study, all three experimental factors (host, temperature treatment, and canopy structure) were found to be important determinants of ECM fungal community structure.

Our initial hypothesis was that ECM fungal community response to increased temperature in a climate and ecosystem characteristic of the boreal-temperate ecotone is dependent on host species, with warming increasing the presence of characteristically temperate ECM fungal taxa on boreal host species. Our premise was that, in order to survive, boreal species growing at the warmer trailing edge of their range will switch their symbionts to taxa that are better adapted to higher temperature [25]. Fungi belonging to long-distance exploration type form rhizomorphs and are hydrophobic and efficiently transport nutrient and water [66] and longer distance exploration type fungal taxa increase across warming [27]. Although we found Suillus species on tree root, data from the current study did not support this hypothesis, as most of the most abundant taxa in our experiment (e.g., Tomentella or Russulaceae) or those that significantly increased at elevated temperature (e.g. Laccaria), equally colonized both temperate and boreal species. In the present study, the examined seedlings were growing under the experimental conditions for 3 years prior to sampling, and therefore, their fungal communities likely reflect experimental rather than nursery conditions. However, we cannot exclude survival of some nursery species on seedling root since data are not consistent showing both survival of some fungal species $[67,68]$ and shaping composition of ECM fungal communities after 2 years chiefly by environmental factors rather than pre-inoculation with different mycorrhizal fungi [69]. Taxa such as Lactarius, Russula, and Tomentella commonly occur in northern temperate ecosystems [reviewed by 38]. Those ECM species are host generalist, which is more common than ECM fungal affiliation towards specific tree species [70-73]. Thus, the absence of specific instances where temperate fungal species switched to roots of boreal species may be explained by the nature of Russulaceae or Thelephoraceae which are generalist ECM fungi and dominated in the experimental plots used in the current study. It has been observed that diversity of ECM fungal community is reduced in mixed forest stands [74]. Thus, the structure of diverse tree species used in our experiment could have also promoted lower ECM species diversity increasing proportion of the ECM fungal generalists. According to Carignan and Villard [75], cosmopolitan fungi are less sensitive to environmental changes than fungi restricted to specific site conditions. Also, Lankau et al. [76] found 
Table 4 Multivariate test (anova.manyglm) of other fungal abundance taxon

\begin{tabular}{llcc}
\hline Factor & Res. Df & Score & $\operatorname{Pr}(>$ score $)$ \\
\hline Canopy & 131 & 390.4 & 0.01 \\
Temperature treatment & 132 & 705.9 & 0.01 \\
species & 134 & 1229.5 & 0.01 \\
Canopy $\times$ temperature treatment & 120 & 274.0 & 0.01 \\
Canopy $\times$ species & 122 & 307.6 & 0.01 \\
Temperature $\times$ species & 125 & 673.5 & 0.01 \\
Canopy $\times$ temperature treatment $\times$ species & 114 & 205.9 & 0.01 \\
\hline
\end{tabular}

less deleterious effects of climate change on ECM relationships growing at the trailing edge of their geographic distribution, suggesting similar conclusions to Fisichelli et al. [11] that climate warming will not cause recession of boreal tree species, but rather, will result in a broadening of the transition zone in which boreal and temperate species exist together.

The most diverse taxa in our study, Inocybe, Cortinarius, and Sebacina, have been previously shown to be most diverse in colder climatic conditions, such as the Arctic [12, 37, 77]. Although 84 ECM OTUs were detected in the present study, most were not very abundant. Response to the environmental conditions administered in this study did not appear to be phylogenetically consistent, with OTUs belonging to the same genus responding differently to the same experimental treatments. Thus, apart from fungal generalists that have wide temperature optima, the diverse responses observed within taxa may indicate that these genera have different temperature optima. Switching from OTUs to another better adapted to changed condition within the same fungal taxa may be another reason why we did not observe temperate ECM fungi on boreal tree species. While this is somewhat in contrast with Tibbett et al. [78], Rygiewicz et al. [30], and LópezGutiérrez et al. [79], who found consistent genus-level responses to temperature, other global change experiments have also observed inconsistent phylogenetic responses, for example to elevated $\mathrm{CO}_{2}[80,81]$.

The warming treatment appeared to affect the foraging type of ECM, which can be classified into "exploration types" based on their ability to form features such as extramatrical mycelia and rhizomorphs, which determine foraging range in the surrounding soil [66]. Examples of common exploration types include a contact exploration type which is characterized by a smooth mantle, few emanating hyphae and very short foraging distance, and a long-distance exploration type capable of forming rhizomorphs that can extend distances in the soil and intermediate type (e.g., medium smooth-forming smooth mantle and rhizomorphs). In our study, warming decreased medium-smooth and contact exploration types, such as Russula (OTU_44), Tomentella (OTU_6), and Clavulina (OTU_30). Deslippe et al. [27] and Jarvis et al. [31] also observed a negative influence of warming on mediumsmooth, contact, and short exploration types. Fungi characterized as short and medium-smooth exploration types have a lower biomass of extramatrical hyphae and are thus able to regenerate more rapidly in response to an environmental disturbance [82]. Growth conditions and belowground C flux, however, enable the colonization of new absorptive roots with fungal communities that are affected by experimental conditions along with previously established ECM fungal species. Thus, stronger mycelial competitors become dominant over time [83]. While foraging types are often interpreted to reflect fungal nutrient uptake strategy [84], they may also reflect a trade-off in root colonization and competition strategies [83, 85]. In this light, the reduction we observed in the presence of ECM fungi that did not form extramatrical mycelia might indicate that they were weaker dispersers under the

Table 5 General linear model of ECM fungal OTU richness based upon the rarefication of the observed species to 50 sequences

\begin{tabular}{|c|c|c|c|c|c|c|c|c|c|c|c|c|c|}
\hline & \multirow[t]{3}{*}{ DF } & \multicolumn{4}{|c|}{ Richness metrics } & \multicolumn{4}{|c|}{ Diversity metrics } & \multicolumn{4}{|c|}{ Evenness metrics } \\
\hline & & \multicolumn{2}{|l|}{ Chaol } & \multicolumn{2}{|c|}{ Observed species } & \multicolumn{2}{|c|}{ Shannon } & \multicolumn{2}{|c|}{ Simpson } & \multicolumn{2}{|c|}{ Shannon } & \multicolumn{2}{|c|}{ Simpson } \\
\hline & & $\mathrm{F}$ & $\mathrm{P}$ & $\mathrm{F}$ & $\mathrm{P}$ & $\mathrm{F}$ & $\mathrm{P}$ & $\mathrm{F}$ & $\mathrm{P}$ & $\mathrm{F}$ & $\mathrm{P}$ & $\mathrm{F}$ & $\mathrm{P}$ \\
\hline species & 3 & 0.132 & 0.941 & 0.147 & 0.931 & 0.015 & 0.998 & 0.084 & 0.968 & 0.013 & 0.998 & 0.344 & 0.794 \\
\hline Temperature treatment & 2 & 0.452 & 0.638 & 0.631 & 0.535 & 1.138 & 0.326 & 0.981 & 0.379 & 1.246 & 0.293 & 0.998 & 0.374 \\
\hline canopy & 1 & 0.044 & 0.834 & 0.005 & 0.164 & 0.013 & 0.909 & 0.011 & 0.918 & 0.006 & 0.939 & 0.092 & 0.763 \\
\hline Temperature $\times$ species & 6 & 1.521 & 0.181 & 1.576 & 0.164 & 1.595 & 0.160 & 1.436 & 0.211 & 1.067 & 0.390 & 1.304 & 0.266 \\
\hline Canopy $\times$ temperature treatment & 2 & 1.124 & 0.330 & 1.468 & 0.236 & 0.545 & 0.582 & 0.673 & 0.513 & 0.133 & 0.876 & 0.509 & 0.603 \\
\hline Canopy $\times$ species & 3 & 1.362 & 0.260 & 1.239 & 0.300 & 0.936 & 0.427 & 0.773 & 0.512 & 0.344 & 0.794 & 0.431 & 0.731 \\
\hline
\end{tabular}


Table 6 General linear model of other fungal OTU richness based upon the rarefication of the observed species to 50 sequences

\begin{tabular}{|c|c|c|c|c|c|c|c|c|c|c|c|c|c|}
\hline & \multirow[t]{3}{*}{$\mathrm{DF}$} & \multicolumn{4}{|c|}{ Richness metrics } & \multicolumn{4}{|c|}{ Diversity metrics } & \multicolumn{4}{|c|}{ Evenness metrics } \\
\hline & & \multicolumn{2}{|l|}{ Chaol } & \multicolumn{2}{|c|}{ Observed species } & \multicolumn{2}{|c|}{ Shannon } & \multicolumn{2}{|c|}{ Simpson } & \multicolumn{2}{|c|}{ Shannon } & \multicolumn{2}{|c|}{ Simpson } \\
\hline & & $\mathrm{F}$ & $\mathrm{P}$ & $\mathrm{F}$ & $\mathrm{P}$ & $\mathrm{F}$ & $\mathrm{P}$ & $\mathrm{F}$ & $\mathrm{P}$ & $\mathrm{F}$ & $\mathrm{P}$ & $\mathrm{F}$ & $\mathrm{P}$ \\
\hline Species & 3 & 2.493 & 0.068 & 1.924 & 0.134 & 2.066 & 0.113 & 2.135 & 0.104 & 1.915 & 0.136 & 1.778 & 0.160 \\
\hline Temperature treatment & 2 & 1.323 & 0.273 & 1.086 & 0.344 & 2.386 & 0.100 & 3.559 & 0.034 & 4.411 & 0.016 & 2.232 & 0.115 \\
\hline Canopy & 1 & 4.164 & 0.045 & 4.335 & 0.041 & 5.707 & 0.020 & 5.857 & 0.018 & 2.624 & 0.110 & 0.881 & 0.351 \\
\hline Temperature $\times$ species & 6 & 2.016 & 0.076 & 1.937 & 0.087 & 2.152 & 0.059 & 1.941 & 0.087 & 1.879 & 0.097 & 1.830 & 0.106 \\
\hline Canopy $\times$ temperature treatment & 2 & 0.651 & 0.585 & 0.314 & 0.815 & 0.051 & 0.984 & 0.132 & 0.941 & 0.353 & 0.787 & 0.298 & 0.827 \\
\hline Canopy $\times$ species & 3 & 4.083 & 0.021 & 3.459 & 0.037 & 2.063 & 0.135 & 1.178 & 0.314 & 1.462 & 0.239 & 0.416 & 0.661 \\
\hline
\end{tabular}

Values matched in italics are statistically significant

environmental conditions used in the present study. Given that short-contact exploration type fungi are more characteristic in high root density conditions [85], and more biomass is allocated to fine roots [6], increasing temperature in our experiment might also decrease the number of fine roots. Despite previously found results of increased participation of ECM fungi characterized with long-distance exploration type in temperate environments in contrast to boreal [64], domination of ECM fungi with short-distance exploration type in our experimental plots may be also the reason why our symbiontswitching hypothesis was not confirmed.

Previous global analyses found that both temperature and precipitation together were important factors affecting ECM fungal richness $[36,86]$. In contrast, increases in ECM fungal OTU richness were not observed in temperate tree species in our study in response to temperature treatments, nor were decreases observed in boreal species. Diminishing richness of ectomycorrhizal species with different physiological and ecological functions may make the community more susceptible to perturbations [87-90]. In this regard, our results suggest that ECM fungi may be adaptable and tolerant to anthropogenic warming, at least up to a point. Additionally, our results may indicate that tree hosts switch their fungal symbionts [as was suggested by 25] to adjust to new conditions (e.g., warming and/or drying conditions) and that fungal community composition can be altered without alteration in richness. Such an adjustment is plausible when the local environment is rich in ECM fungal inocula. A shift in species richness is mainly driven by rare species that are more sensitive to unfavorable environmental conditions [36] or changes in soil attributes [63, 90]. The lack of differences in fungal richness observed in the present study, despite the richness in host species in experimental plots, may be due to dominance of the generalist species that were found on roots rather than specialist/rare species of ECM fungi. On the other hand, as suggested by Jarvis et al. [31] and Coince et al. [91], no difference in ECM fungal richness may be the result of insufficient saturation of the rarefied sampling curve and a deficiency in the identification of all the ECM fungal taxa inhabiting the root system of the tree species present in the experimental plots.

The higher energy influx in the open canopy was hypothesized to support a greater ECM richness. This hypothesis was not confirmed in our study, but a similar result was also reported in a tropical rainforest ECM community where it was interpreted as a decrease in the availability of local ECM inoculum supported by overstory trees [63]. However, the open canopy plots were established in near distance to the forest border on site where tree stumps were cut to the height less than $30 \mathrm{~cm} 1$ year before the appropriate experiments stated [39]. Thus, the fungal inoculum may not be an issue. Given the linear relationship between gross primary productivity and carbon fluxes to both above and belowground plant organs [92], an increase in the supply of carbohydrates belowground should have promoted ECM richness in our experimental study. Reich et al. [18] demonstrated that, in contrast to the temperate species Q. rubra, warming negatively affect the physiology (net photosynthesis and growth) of the boreal species $P$. glauca. Additionally, they observed a neutral response to simulated warming in the boreal species, $B$. papyrifera and the temperate species, $P$. strobus [18]. When growing in an open versus a closed canopy, P. glauca and $Q$. rubra species responded differently to simulated warming [18]. ECM fungal richness in our studies did not correspond to changes in host photosynthesis. Interpreting this finding illustrates the complexity of predicting responses of mutualistic communities, since their responses are affected directly and indirectly by tree physiology as well as their own direct responses to environmental changes. Thus, the response of the ECM fungal community may be affected 
directly by specific experimental factors and indirectly by environmental conditions, both of which may alter the response of the ECM fungal community to host species.

\section{Conclusion}

In the present study, we investigated the effect of projected increases in global temperatures on root-associated fungi of boreal and temperate tree species, as well as how canopy structure (open vs. closed) may interact with the potential impact of elevated soil temperatures. We hypothesized that ECM fungal richness would increase for temperate hosts and decrease for boreal hosts in warmed plots, and ECM fungal community composition in warmed treatments would be dominated by fungi found on temperate host plants. Additionally, we expected richness would increase in open canopy plots. In contrast to our initial hypothesis, no changes in ECM fungal richness were observed in response to simulated warming in either boreal or temperate tree species. While ECM richness has been shown to change over latitudinal gradients of climatic conditions [86], our data suggest that temperature changes in the range of $1-4{ }^{\circ} \mathrm{C}$ may exert a lesser impact on the diversity of root symbiotic fungi when plant species and precipitation are held constant. We did find, however, that canopy structure, experimental warming, and tree species affected the species composition of ECM fungi. In the future, additional detailed studies are warranted and necessary in order to provide additional information pertaining to the functional response of ectomycorrhizal fungi to different environmental drivers. It is plausible that long-term warming may change the soil mineralization rate, which in turn may lead to the selection of fungi with different abilities to uptake $\mathrm{N}$ and $\mathrm{P}$. Whether these community changes buffer or further exacerbate changes in ecosystem function will depend on how the traits that determine response to nutrient availability are linked with other functional traits that affect ecosystem function [93]. Previous experiments have indicated that ECM community composition is affected by climatic factors while community function is dependent upon local soil conditions [94, 95]. Collectively, the data of the present study and previous studies suggest that further experiments will be required in order to more definitively understand the factors that determine the large-scale patterns in ECM community composition.

Acknowledgements We are grateful for the help provided by students for the harvesting of plant materials. We would like to extend special thanks to Karen Rice who contributed to the establishment, operation, and maintenance of the experimental site. The research presented in this paper was funded as the B4WarmED project by the US Department of Energy Program on Ecological Research (grant no. DE-FG0207ER64456); the College of Food, Agricultural and Natural Resource Sciences (CFANS) at University of Minnesota; and the Minnesota Environment and Natural Resources Trust Fund. Joanna Mucha also received financial support from the National Science Centre, Poland (Project no. 2011/01/D/NZ9/02871), Institute of Dendrology, Polish Academy of Science. Joanna Mucha wants to thank Prof. Jacek Oleksyn, Director of the Institute of Dendrology in Kornik, for the establishment the collaboration necessary for this paper.

Open Access This article is distributed under the terms of the Creative Commons Attribution 4.0 International License (http:// creativecommons.org/licenses/by/4.0/), which permits unrestricted use, distribution, and reproduction in any medium, provided you give appropriate credit to the original author(s) and the source, provide a link to the Creative Commons license, and indicate if changes were made.

\section{References}

1. Moritz RE, Bitz CM, Steig EJ (2002) Dynamics of recent climate change in the Arctic Science 297(5586):1497-1502. doi:10.1126/science.1076522

2. IPCC (2014) Summary for policymakers. In: Field CB, Barros VR, Dokken DJ, Mach KJ, Mastrandrea MD, et al. (eds) Climate change 2014: impacts, adaptation, and vulnerability. Part a: global and sectoral aspects. Contribution of working group II to the fifth assessment report of the intergovernmental panel on climate change. Cambridge University Press, Cambridge, pp. 1-32

3. Hampe A, Petit RJ (2005) Conserving biodiversity under climate change: the rear edge matters Ecol. Lett. 8(5):461-467. doi:10.1111/j.1461-0248.2005.00739.x

4. Bronson DR, Gower ST, Tanner M, Linder S, Van Herk I (2008) Response of soil surface $\mathrm{CO}_{2}$ flux in a boreal forest to ecosystem warming Glob. Chang. Biol. 14(4):856-867. doi:10.1111/j.13652486.2007.01508.x

5. Stokstad E (2004) Defrosting the carbon freezer of the north Science 304(5677):1618-1620. doi:10.1126/science.304.5677. 1618

6. Reich PB, Luo YJ, Bradford JB, Poorter H, Perry CH, Oleksyn J (2014) Temperature drives global patterns in forest biomass distribution in leaves, stems, and roots Proc Natl Aca Sci U S A 111(38): 13721-13726. doi:10.1073/pnas.1216053111

7. Zadworny M, McCormack ML, Mucha J, Reich PB, Oleksyn J (2016) Scots pine fine roots adjust along a 2,000 km cold-climate gradient New Phytol. 212(2):389-399. doi:10.1111/nph.14048

8. Brassard BW, Chen HYH, Bergeron Y (2009) Influence of environmental variability on root dynamics in northern forests Crit. Rev. Plant Sci. 28(3):179-197. doi:10.1080/07352680902776572

9. Hobbie JE, Hobbie EA (2006) ${ }^{15} \mathrm{~N}$ in symbiotic fungi and plants estimates nitrogen and carbon flux rates in Arctic tundra Ecology 87:816 822. doi:10.1890/0012-9658(2006)87[816:NISFAP]2.0.CO;2

10. Kivlin SN, Emery SM, Rudgers JA (2013) Fungal symbionts alter plant responses to global change Am. J. Bot. 100(7):1445-1457. doi:10.3732/ajb.1200558

11. Fisichelli NA, Frelich LE, Reich PB (2014) Temperate tree expansion into adjacent boreal forest patches facilitated by warmer temperatures Ecography 37(2):152-161. doi:10.1111/j.1600-0587. 2013.00197.x

12. Söderström B (2002) Challenges for mycorrhizal research into the new millennium Plant Soil 244(1-2):1-7. doi:10.1007/978-94-0171284-2 1

13. Johnson D, IJdo M, Genney DR, Anderson IC, Alexander IJ (2005) How do plants regulate the function, community structure, and diversity of mycorrhizal fungi? J. Exp. Bot. 56(417):1751-1760. doi:10.1093/jxb/eri192

14. Ekblad A, Wallander H, Godbold DL, Cruz C, Johnson D, Baldrian P, et al. (2013) The production and turnover of extramatrical 
mycelium of ectomycorrhizal fungi in forest soils: role in carbon cycling Plant Soil 366(1-2):1-27. doi:10.1007/s11104-013-1630-3

15. Smith SE, Read DJ (2008) Mycorrhizal symbiosis. Academic, New York,

16. Simard SW, Jones MD, Durall DM (2002) Carbon and nutrient fluxes within and between mycorrhizal plants. In: van der Heijden MGA, Sanders IR (eds) Mycorrhizal ecology. Springer, Berlin, pp. 33-74

17. Wallander H, Johansson U, Sterkenburg E, Brandström Durling M, Lindahl BD (2010) Production of ectomycorrhizal mycelium peaks during canopy closure in Norway spruce forests New Phytol. 187(4):1124-1134. doi:10.1111/j.1469-8137.2010.03324.x

18. Reich PB, Sendall KM, Rice K, Rich RL, Stefanski A, Hobbie SE, Montgomery RA (2015) Geographic range predicts photosynthetic and growth response to warming in co-occurring tree species Nat. Clim. Chang. 5:148-152. doi:10.1038/nclimate2497

19. Fernandez CW, Nguyen N, Stefanski A, Han Y, Hobbie SE, Montgomery RA, Reich PB, Kennedy PG (2017) Ectomycorrhizal fungal response to warming is linked to poor host performance at the boreal-temperate ecotone. Glob Chang Biol 23(4):1598-1609. doi:10.1111/gcb.13510

20. Druebert C, Lang C, Valtanen K, Polle A (2009) Beech carbon productivity as driver of ectomycorrhizal abundance and diversity Plant Cell Environ. 32(8):992-1003. doi:10.1111/j.1365-3040. 2009.01983.x

21. Hasselquist NJ, Metcalfe DB, Inselsbacher E, Stangl Z, Oren R, Näsholm T, Högberg P (2016) Greater carbon allocation to mycorrhizal fungi reduces tree nitrogen uptake in a boreal forest Ecology 97(4):1012-1022. doi:10.1890/15-1222.1

22. Pietikäinen J, Pettersson M, Bååth E (2005) Comparison of temperature effects on soil respiration and bacterial and fungal growth rates FEMS Microbiol. Ecol. 52(1):49-58. doi:10.1016/j.femsec.2004. 10.002

23. Jousset A, Schmid B, Scheu S, Eisenhauer N (2011) Genotypic richness and dissimilarity opposingly affect ecosystem functioning Ecol. Lett. 14(6):537-545. doi:10.1111/j.1461-0248.2011.01613.x

24. Hortal S, Powell JR, Plett JM, Simonin A, Anderson IC (2016) Intraspecific competition between ectomycorrhizal Pisolithus microcarpus isolates impacts plant and fungal performance under elevated $\mathrm{CO}_{2}$ and temperature FEMS Microbiol. Ecol. 92(8): fiw113. doi:10.1093/femsec/fiw113

25. Jones AM, Berkelmans R, van Oppen MJ, Mieog JC, Sinclair W (2008) A community change in the algal endosymbionts of a scleractinian coral following a natural bleaching event: field evidence of acclimatization Proc R Soc Lond B Biol Sci 275(1641): 1359-1365. doi:10.1098/rspb.2008.0069

26. Clemmensen KE, Michelsen A, Jonasson S, Shaver GR (2006) Increased ectomycorrhizal fungal abundance after long-term fertilization and warming of two arctic tundra ecosystems New Phytol. 171(2):391-404. doi:10.1111/j.1469-8137.2006.01778.x

27. Deslippe JR, Hartmann M, Mohn WW, Simard SW (2011) Longterm experimental manipulation of climate alters the ectomycorrhizal community of Betula nana in Arctic tundra Glob. Chang. Biol. 17(4):1625-1636. doi:10.1111/j.1365-2486. 2010.02318.x

28. Allison SD, Treseder KK (2008) Warming and drying suppress microbial activity and carbon cycling in boreal forest soils Glob. Chang. Biol. 14(12):2898-2909. doi:10.1111/j.1365-2486.2008. 01716.x

29. Domisch T, Finér L, Lehto T, Smolander A (2002) Effect of soil temperature on nutrient allocation and mycorrhizas in Scots pine seedlings Plant Soil 239(2):173-185. doi:10.1023/A: 1015037127126

30. Rygiewicz PT, Martin KJ, Tuininga AR (2000) Morphotype community structure of ectomycorrhizas on Douglas fir (Pseudotsuga menziesii Mirb. Franco) seedlings grown under elevated atmospheric $\mathrm{CO}_{2}$ and temperature Oecologia 124(2):299-308. doi: $10.1007 / \mathrm{s} 004420000385$

31. Jarvis S, Woodward S, Alexander IJ, Taylor AFS (2013) Regional scale gradients of climate and nitrogen deposition drive variation in ectomycorrhizal fungal communities associated with native Scots pine Glob. Chang. Biol. 19(6):1688-1696. doi:10.1111/gcb.12178

32. Timling I, Dahlberg A, Walker DA, Gardes M, Charcosset JY, Welker JM, Taylor DL (2012) Distribution and drivers of ectomycorrhizal fungal communities across the north American Arctic Ecosphere 3(11):art111. doi:10.1890/ES12-00217.1

33. Põlme S, Bahram M, Yamanaka T, et al. (2013) Biogeography of ectomycorrhizal fungi associated with alders (Alnus spp.) in relation to biotic and abiotic variables at the global scale New Phytol. 198(4):1239-1249. doi:10.1111/nph.12170

34. Ishida TA, Nara K, Hogetsu T (2007) Host effects on ectomycorrhizal fungal communities: insight from eight host species in mixed conifer-broadleaf forests New Phytol. 174(2):430 440. doi:10.1111/j.1469-8137.2007.02016.x

35. Tedersoo L, Suvi T, Jairus T, Kõljalg U (2008) Forest microsite effects on community composition of ectomycorrhizal fungi on seedlings of Picea abies and Betula pendula Environ. Microbiol. 10(5):1189-1201. doi:10.1111/j.1462-2920.2007.01535.x

36. Bahram M, Põlme S, Kõljalg U, Zarre S, Tedersoo L (2012) Regional and local patterns of ectomycorrhizal fungal diversity and community structure along an altitudinal gradient in the Hyrcanian forests of northern Iran New Phytol. 193(2):465-473. doi:10.1111/j.1469-8137.2011.03927.x

37. Bjorbækmo M, Carlsen T, Brysting A, et al. (2010) High diversity of root associated fungi in both alpine and arctic Dryas octopetala BMC Plant Biol. 10(1):244. doi:10.1186/1471-2229-10-244

38. Tedersoo L, Nara K (2010) General latitudinal gradient of biodiversity is reversed in ectomycorrhizal fungi New Phytol. 185(2):351354. doi:10.1111/j.1469-8137.2009.03134.x

39. Rich RL, Stefanski A, Montgomery RA, Hobbie SE, Kimball BA, Reich PB (2015) Design and performance of combined infrared canopy and belowground warming in the B4WarmED (boreal Forest warming at an ecotone in danger) experiment Glob Chang Biol 21(6):2334-2348. doi:10.1111/gcb.12855

40. Way DA, Oren R (2010) Differential responses to changes in growth temperature between trees from different functional groups and biomes: a review and synthesis of data. Tree Physiol 30(6): 669-688. doi:10.1093/treephys/tpq015

41. Peay KG, Kennedy PG, Davies SJ, Tan S, Bruns TD (2010) Potential link between plant and fungal distributions in a dipterocarp rainforest: community and phylogenetic structure of tropical ectomycorrhizal fungi across a plant and soil ecotone New Phytol. 185(2):529-542. doi:10.1111/j.1469-8137.2009.03075.x

42. Gardes M, Bruns T (1993) ITS primers with enhanced specificity for Basidiomycetes-application to the identification of mycorrhizae and rusts Mol. Ecol. 2(2):113-118. doi:10.1111/j.1365-294X.1993. tb00005.x

43. White T, Bruns T, Lee S, Taylor J (1990) Amplification and direct sequencing of fungal ribosomal RNA genes for phylogenetics PCR Protocols 315:322

44. Caporaso JG, Kuczynski J, Stombaugh J, et al. (2010) QIIME allows analysis of high-throughput community sequencing data Nat. Methods 7(5):335-336. doi:10.1038/nmeth.f.303

45. Edgar RC (2010) Search and clustering orders of magnitude faster than BLAST Bioinformatics 26(19):2460-2461. doi:10.1093/ bioinformatics/btq461

46. Kõljalg U, Nilsson RH, Abarenkov K, Tedersoo L, Taylor AF, Bahram M, et al. (2013) Towards a unified paradigm for sequence-based identification of fungi Mol. Ecol. 22(21):52715277. doi:10.1111/mec. 12481

47. Tedersoo L, May TW, Smith ME (2010) Ectomycorrhizal lifestyle in fungi: global diversity, distribution, and evolution of 
phylogenetic lineages Mycorrhiza 20(4):217-263. doi:10.1007/ s00572-009-0274-x

48. Branco S, Bruns TD, Singleton I (2013) Fungi at a small scale: spatial zonation of fungal assemblages around single trees PLoS One 8(10):e78295. doi:10.1371/journal.pone.0078295

49. Bellemain E, Carlsen T, Brochmann C, Coissac E, Taberlet P, Kauserud H (2010) ITS as an environmental DNA barcode for fungi: an in silico approach reveals potential PCR biases BMC Microbiol. 10(1):189. doi:10.1186/1471-2180-10-189

50. Porter TM, Golding GB (2012) Factors that affect large subunit ribosomal DNA amplicon sequencing studies of fungal communities: classification method, primer choice, and error PLoS One 7(4): e35749. doi:10.1371/journal.pone.0035749

51. Pukkila PJ, Skrzynia C (1993) Frequent changes in the number of reiterated ribosomal RNA genes throughout the life cycle of the basidiomycete Coprinus cinereus Genetics 133(2):203-211

52. Rooney AP, Ward TJ (2005) Evolution of a large ribosomal RNA multigene family in filamentous fungi: birth and death of a concerted evolution paradigm Proc. Natl. Acad. Sci. U. S. A. 102(14): 5084-5089. doi:10.1073/pnas.0409689102

53. McMurdie PJ, Holmes S (2014) Waste not, want not: why rarefying microbiome data is inadmissible PLoS Comput. Biol. 10(4): e1003531. doi:10.1371/journal.pcbi.1003531

54. Smith DP, Peay KG (2014) Sequence depth, not PCR replication, improves ecological inference from next generation DNA sequencing PLoS One 9(2):e90234. doi:10.1371/journal.pone.0090234

55. Amend AS, Seifert KA, Bruns TD (2010) Quantifying microbial communities with 454 pyrosequencing: does read abundance count? Mol. Ecol. 19(24):5555-5565. doi:10.1111/j.1365-294X. 2010.04898.x

56. Wang Y, Naumann U, Wright ST, Warton DI (2012) Mvabund — an $\mathrm{R}$ package for model-based analysis of multivariate abundance data Methods Ecol. Evol. 3(3):471-474. doi:10.1111/j.2041-210X. 2012.00190.x

57. Warton DI, Wright ST, Wang Y (2012) Distance-based multivariate analyses confound location and dispersion effects Methods Ecol. Evol. 3(1):89-101. doi:10.1111/j.2041-210X.2011.00127.x

58. Warton DI (2005) Many zeros does not mean zero inflation: comparing the goodness of-fit of parametric models to multivariate abundance data Environmetrics 16(3):275-289. doi:10.1002/env.702

59. Bruns TD, Bidartondo MI, Taylor DL (2002) Host specificity in ectomycorrhizal communities: what do the exceptions tell us? Integr. Comp. Biol. 42(2):352-359. doi:10.1093/icb/42.2.352

60. Smith ME, Douhan GW, Fremier AK, Rizzo DM (2009) Are true multihost fungi the exception or the rule? Dominant ectomycorrhizal fungi on Pinus sabiniana differ from those on co-occurring Quercus species New Phytol. 182(2):295-299. doi: $10.1111 / j .1469-8137.2009 .02801 . x$

61. Molina R, Massicotte H, Trappe JM (1992) Specificity phenomena in mycorrhizal symbioses: community-ecological consequences and practical implications. In: Allen MJ (ed) Mycorrhizal functioning: an integrative plant-fungal process. Springer Science \& Business Media, Dordrecht, pp. 357-423

62. Cox F, Barsoum N, Lilleskov EA, Bidartondo MI (2010) Nitrogen availability is a primary determinant of conifer mycorrhizas across complex environmental gradients Ecol. Lett. 13(9):1103-1113. doi: 10.1111/j.1461-0248.2010.01494.x

63. Peay KG, Russo SE, McGuire KL, Lim Z, Chan JP, Tan S, Davies SJ (2015) Lack of host specificity leads to independent assortment of dipterocarps and ectomycorrhizal fungi across a soil fertility gradient Ecol. Lett. 18(8):807-816. doi:10.1111/ele.12459

64. Ostonen I, Helmisaari HS, Borken W, et al. (2011) Fine root foraging strategies in Norway spruce forests across a European climate gradient Glob. Chang. Biol. 17(12):3620-3632. doi:10.1111/j. 1365-2486.2011.02501.x
65. Roy M, Rochet J, Manzi S, Jargeat P, Gryta H, Moreau P-A, et al. (2013) What determines Alnus-associated ectomycorrhizal community diversity and specificity? A comparison of host and habitat effects at a regional scale New Phytol. 198:1228-1238. doi:10.1111/ nph. 12212

66. Agerer R (2001) Exploration types of ectomycorrhizae Mycorrhiza 11(2):107-114. doi:10.1007/s005720100108

67. Franco AR, Sousa NR, Ramos MA, Oliveira RS, Castro PM (2014) Diversity and persistence of ectomycorrhizal fungi and their effect on nursery-inoculated Pinus pinaster in a post-fire plantation in northern Portugal Microb. Ecol. 68(4):761-772. doi:10.1007/ s00248-014-0447-9

68. Gagné A, Jany JL, Bousquet J, Khasa DP (2006) Ectomycorrhizal fungal communities of nursery-inoculated seedlings outplanted on clear-cut sites in northern Alberta Can. J. For. Res. 36(7):1684 1694. doi:10.1139/x06-063

69. Menkis A, Vasiliauskas R, Taylor AFS, Stenlid J, Finlay R (2007) Afforestation of abandoned farmland with conifer seedlings inoculated with three ectomycorrhizal fungi-impact on plant performance and ectomycorrhizal community Mycorrhiza 17(4):337348. doi:10.1007/s00572-007-0110-0

70. Horton TR, Bruns TD (1998) Multiple-host fungi are the most frequent and abundant ectomycorrhizal types in a mixed stand of Douglas fir (Pseudotsuga menziesii) and bishop pine (Pinus muricata) New Phytol. 139:331-339. doi:10.1046/j.1469-8137. 1998.00185.x

71. Horton TR, Bruns TD, Parker VT (1999) Ectomycorrhizal fungi associated with Arctostaphylos contribute to Pseudotsuga menziesii establishment Can. J. Bot. 77(1):93-102. doi:10.1139/b98-208

72. Cullings KW, Vogler DR, Parker VT, Finley SK (2000) Ectomycorrhizal specificity patterns in a mixed Pinus contorta and Picea engelmannii forest in Yellowstone national park Appl. Environ. Microbiol. 66(1):4988-4991. doi:10.1128/AEM.66.11. 4988-4991.2000

73. Kennedy PG, Izzo AD, Bruns TD (2003) There is high potential for the formation of common mycorrhizal networks between understorey and canopy trees in a mixed evergreen forest J. Ecol. 91(6): 1071-1080. doi:10.1046/j.1365-2745.2003.00829.x

74. Jones MD, Durall DM, Harniman SMK, Classen DC, Simard SW (1997) Ectomycorrhizal diversity on Betula papyrifera and Pseudotsuga menziesii seedlings grown in the greenhouse or outplanted in single-species and mixed plots in southern British Columbia Can. J. For. Res. 27(11):1872-1889. doi:10.1139/x97-160

75. Carignan V, Villard MA (2002) Selecting indicator species to monitor ecological integrity: a review Environm Monit Assess 78(1): 45-61. doi:10.1023/A:1016136723584

76. Lankau RA, Zhu K, Ordonez A (2015) Mycorrhizal strategies of tree species correlate with trailing range edge responses to current and past climate change Ecology 96(6):1451-1458. doi:10.1890/ 14-2419.1

77. Ryberg M, Larsson E, Molau U (2009) Ectomycorrhizal diversity on Dryas octopetala and Salix reticulata in an alpine cliff ecosystem Arct. Antarct. Alp. Res. 41:506-514. doi:10.1657/1938-424641.4.506

78. Tibbett M, Sanders FE, Cairney JWG (1998) The effect of temperature and inorganic phosphorus supply on growth and acid phosphatase production in arctic and temperate strains of ectomycorrhizal Hebeloma spp. in axenic culture Mycol. Res. 102(02):129-135. doi:10.1017/S0953756297004681

79. López-Gutiérrez JC, Malcolm GM, Koide RT, Eissenstat DM (2008) Ectomycorrhizal fungi from Alaska and Pennsylvania: adaptation of mycelial respiratory response to temperature? New Phytol. 180:741-744. doi:10.1111/j.1469-8137.2008.02655.x

80. Parrent JL, Morris WF, Vilgalys R (2006) $\mathrm{CO}_{2}$-enrichment and nutrient availability alter ectomycorrhizal fungal communities 
Ecology 87:2278-2287. doi:10.1890/0012-9658(2006)87[2278: CANAAE]2.0.CO;2

81. Parrent JL, Vilgalys R (2007) Biomass and compositional responses of ectomycorrhizal fungal hyphae to elevated $\mathrm{CO}_{2}$ and nitrogen fertilization New Phytol. 176:164-174. doi:10.1111/j. 1469-8137.2007.02155.x

82. Tedersoo L, Smith ME (2013) Lineages of ectomycorrhizal fungi revisited: foraging strategies and novel lineages revealed by sequences from belowground Fungal Biol Rev 27(3-4):83-99. doi: 10.1016/j.fbr.2013.09.001

83. Kennedy PG, Higgins LM, Rogers RH, Weber MG (2011) Colonization-competition tradeoffs as a mechanism driving successional dynamics in ectomycorrhizal fungal communities PLoS One 6(9):e25126. doi:10.1371/journal.pone.0025126

84. Hobbie EA, Agerer R (2010) Nitrogen isotopes in ectomycorrhizal sporocarps correspond to belowground exploration types Plant Soil 327:71-83. doi:10.1007/s11104-009-0032-z

85. Peay K, Kennedy P, Bruns T (2011) Rethinking ectomycorrhizal succession: are root density and hyphal exploration types drivers of spatial and temporal zonation? Fungal Ecol. 4:233-240. doi:10. 1016/j.funeco.2010.09.010

86. Tedersoo L, Bahram M, Toots M, et al. (2012) Towards global patterns in the diversity and community structure of ectomycorrhizal fungi Mol. Ecol. 21(17):4160-4170. doi:10.1111/ j.1365-294X.2012.05602.x

87. Tilman D (1996) Biodiversity: population versus ecosystem stability Ecology 77:350-363. doi:10.2307/2265614
88. Tilman D, Downing JA (1994) Biodiversity and stability in grasslands Nature 367:363-365. doi:10.1038/367363a0

89. McGrady-Steed J, Harris PM, Morin PJ (1997) Biodiversity regulates ecosystem predictability Nature 390(6656):162-165. doi:10. $1038 / 36561$

90. Avis P, Mueller G, Lussenhop J (2008) Ectomycorrhizal fungal communities in two north American oak forests respond to nitrogen addition New Phytol. 179:472-483. doi:10.1111/j.1469-8137. 2008.02491.x

91. Coince A, Cordier T, Lengellé J, Defossez E, Vacher C, Robin C, Buée M, Marçais B (2014) Leaf and root-associated fungal assemblages do not follow similar elevational diversity patterns PLoS One 9:e100668. doi:10.1371/journal.pone.0100668

92. Litton CM, Raich JW, Ryan MG (2007) Carbon allocation in forest ecosystems Glob. Chang. Biol. 13(10):2089-2109. doi:10.1111/j. 1365-2486.2007.01420.x

93. Koide RT, Courty PE, Garbaye J (2007) Research perspectives on functional diversity in ectomycorrhizal fungi New Phytol. 174(2): 240-243. doi:10.1111/j.1469-8137.2007.01987.x

94. Talbot JM, Bruns TD, Taylor JW, et al. (2014) Endemism and functional convergence across the north American soil mycobiome Proc. Natl. Acad. Sci. U. S. A. 111(17):6341-6346. doi:10.1073/ pnas. 1402584111

95. Tedersoo L, Bahram M, Põlme S, et al. (2014) Global diversity and geography of soil fungi Science 346(6213):1256688. doi:10.1126/ science. 1256688 